UDC 378.147.091:005.95:004.773.1

JEL Classification: 015

DOI 10.35433/ISSN2410-3748-2021-1(28)-3

\author{
Kaschuck Kateryna, \\ Candidate of economic sciences, \\ Senior lecturer at the Department of Economics, \\ management, marketing and hotel and restaurant business \\ Ivan Franko Zhytomyr State University \\ http: //ORCID 0000-0002-4916-6867
}

\title{
STUDENTS' SELF-MANAGEMENT TECHNOLOGIES AS THE BASIS OF EFFECTIVE DISTANCE LEARNING
}

\begin{abstract}
Annotation. The urgency of the problem of distance education development is caused by the fact that in modern conditions the requirements for specialists are radically changing. At the same time, the central place is not the use of previously acquired knowledge, but the generation and implementation of new ideas, which dictates new requirements for training. In this regard,

lifelong learning becomes increasingly necessary, acquires new forms and meanings. Today, advances in information technology and telecommunications allow the development of distance learning as a kind of continuing education that accompanies the information society, because it forms a comprehensively developed personality, able to navigate in the information environment.

The pandemic forced universities to switch to e-Learning in a force majeure mode, which served as a powerful impetus for the accelerated arming of universities with resources that allow them to effectively practice online and blended learning. In these conditions, it became possible

to implement a student-centered educational paradigm. However, this is hindered by the problem of the student's lack of self-organization and self-motivation skills, the ability to take responsibility for their own learning and development. This problem is gaining more and more theoretical and practical importance. The purpose of the work is to substantiate that courses such as self-management and time management contribute to the formation of competencies in

the field of goal-setting, planning, self-organization, self-control and self-motivation, and, therefore, in the context of the implementation of student-centered pagadigma, they should serve as preliminary study for e-Learning. For this, the article provides a review of the "Time Management" content course in relation to the task of developing proactivity and the student's ability to systematically and productively independent work.

Keywords: e-Learning, distant learning, blended learning, student-centered paradigm, student-centered learning, self-management, time-management, self-organization, selfmotivation, proactivity.
\end{abstract}

\section{ТЕХНОЛОГІЇ САМОМЕНЕДЖМЕНТУ СТУДЕНТІВ ЯК ОСНОВИ ЕФЕКТИВНОГО ДИСТАНЦЙНОГО НАВЧАННЯ}

Анотація. Актуальність проблеми розвитку дистанційного навчання зумовлена тим, щуо в сучасних умовах вимоги до фахівців докорінно змінюються. При цуьому центральне місце займає не використання раніше набутих знань, а генерація та реалізачія нових ідей, що диктує нові вимоги до навчання. Узв'язку з цим навчання

(C) Kaschuck Kateryna 
впродовж життя стає все більш необхідним, набуває нових форм та значення. Сьогодні досягнення інформачійних технологій та телекомунікацій дозволяють розвивати дистанційне навчання як різновид безперервної освіти, щзо супроводжує економіку знань, оскільки вона формує всебічно розвинену особистість, здатну орієнтуватися в інформаційному середовищі.

Пандемія змусила університети перейти на електронне навчання в режимі форсмажсорних обставин, що послужило потужним поштовхом для прискореного озброєння університетів ресурсами, що дозволяють їм ефективно практикувати електронне навчання та змішане навчання. В ијих умовах стало можливим реалізувати студентоорієнтовану освітню парадигму. Однак иььому заважає проблема відсутності у студента самоорганізації та навичок самомотиваиії, здатності нести відповідальність за власне навчання та розвиток. Ця проблема набуває дедалі більше теоретичного та практичного значення. Метою роботи є обтрунтування того, щуо такі дисиипліни, як самоменеджмент

та управління часом, сприяють формуванню компетенцій у галузі иілепокладання, планування, самоорганізаџії, самоконтролю та самомотиващії. В статті доведено, щзо в контексті реалізаиії студентоорієнтованої пагадигми технології самоменеджменту мають бути обов 'язково опановані студентами з метою підвищення ефективності дистаниіийного навчання. Для цьього в статті подано огляд змістового модуля «Самоменеджмент» стосовно завдання розвитку проактивності та здатності студента систематично та продуктивно самостійно працювати.

Ключові слова: електронне навчання, дистанційне навчання, змішане навчання, орієнтована на студентів парадигма, орієнтоване на студента навчання, самоменеджмент, управління часом, самоорганізація, самомотиваџія, проактивність.

\section{Problem statement in general and its connection with important} scientific and practical problems. In March 2020, universities, whether they wanted it or not, were forced to switch to distant learning (e-Learning). Of course, universities, at least for the most part, have been practicing digitalization for a long time. So, according to a survey by the International Association of Universities, in the world before the start of the Covid-19 epidemic, 56\% of respondents used digital technologies to a certain extent, and $31 \%$ of respondents indicated that such technologies are fully integrated into education. With regard to blended and online learning, as well as the "flipped classroom" model $[1 ; 2]$, then $52 \%$ of the respondents used them to some extent, and 27\% - completely [3]. However, in our article we are talking about a total transition to distance learning for an indefinite period. Therefore, at the initial stage, universities faced a variety of problems from servers "falling" from overloading to teachers "falling" from fatigue.

From the standpoint of administrative and managerial personnel, the work of teachers should have become much less, but in practice everything turned out to be exactly the opposite. The student contingent studying full-time education was 
clearly not happy with the forced distance. Parents who were afraid that their children would receive less knowledge, especially when it came to non-budget education, were also nervous. Therefore, the teachers were careful to ensure that the students were sufficiently busy. Assignments multiplied, were completed by students at a convenient time for them, and were sent to teachers at very different times. In fact, the teachers were "filled up" around the clock with incoming work, which had to be promptly checked and commented in detail, providing feedback.

At the same time, thanks to the experience gained, universities have made a real breakthrough in the use of distance learning technologies and significantly "pumped up their muscles" in terms of preparing the relevant content. The situation with the coronavirus, on the one hand, drives us into stress, and on the other hand, it allows us to experience and make the most of those technologies that we have been gradually introducing at our university for a number of years [4].

Today, universities are much more equipped with resources for the implementation of distant learning, which they will certainly strive to use. Given the fact that the covid-19 epidemic is still in full swing, it is possible that universities will again be forced to switch to distance learning, or at least to the socalled blended learning, the idea of which is not new, but the moment for its introduction and widespread rooting is now the most suitable. In addition, this educational technology allows you to get closer to implementation of the modern pedagogical paradigm of student-centered learning $[5 ; 6]$.

Student-centered learning represents a type of thinking and culture of a higher education institution, as well as a teaching method that is strongly associated with and reinforced by constructivist theories of learning. Studentcentered learning is characterized by innovative teaching methods that stimulate learning in collaboration between teachers and learners and take students seriously as active participants in their own learning, developing transferable skills such as problem solving, critical thinking and reflective thinking.

Analysis of recent research and publications. Topics of higher education publications relate mainly to seven topics: online learning; internationalization of (c) Kaschuck Kateryna 
education; scientific research and conferences; finances; strategy, quality of education and interaction with the state [2].

On a global scale, UNESCO scientists are most actively involved in the issue of forced distance learning. They note that most applicants for higher education at all levels have become virtually isolated in the cities, it is the cities that have taken a "front line" in the fight against new challenges and problems [3]. One of the methods is the formation of so-called "Learning cities", i.e. cities that effectively mobilize resources for education, rethink learning in households and civil society, use modern technologies for online learning through which the city has the potential to expand opportunities. and social integration, economic development, cultural prosperity and sustainable development [4].

Within the framework of the concept of "Learning cities" it is important to provide not only formal but also non-formal education for all comers. Those cities that have integrated non-formal education programs through collaboration with local organizations and firms have expanded the potential for urbanization into "learning cities". Examples of such collaboration among local government structures or with the involvement of other private organizations are: the opening of free courses for students and pupils of schools or the free use of online library catalogs. In addition, the development of such online or digital programs is aimed at changing people's behavior and way of thinking, which has become a priority during the rapid spread of the pandemic [5].

The purpose of the work is to analyze features of the student-centered approach to distance learning in system of higher education and to define advantages and lacks of its functioning.

Presentation of the main research material. Distance learning is based on a competency-based approach, the requirements of which are best met by the student-centered learning paradigm. This paradigm assumes the active participation of the student in education. It belongs to the constructivist models that put the student at the forefront of the educational process. 
"Constructivists proceed from the fact that the source of development of students is interaction with the environment, which gives them the opportunity to self-develop" [8]. Within the framework of constructivist models, much attention is paid to productive learning [9], in which the indirect transfer of knowledge from the teacher to the student dominates [10], and independent discovery of new knowledge by students in the process of working with information, project activities, reflections and discussions. All this requires a fundamentally new approach to the creation of teaching materials, to the organization of the educational process, to the professional qualifications of a teacher.

The role of the teacher changes: from the lecturer - to the moderator and facilitator, from the mentor - to the mentor who helps the student to effectively search for information and master the educational material on his own. But that's not all. The main thing is that in this paradigm, the student independently forms his educational trajectory, which, in essence, requires the implementation of individually oriented learning.

In full-time education today, such an approach desperately conflicts with the universally accepted flow-group organization of training, but in the conditions of e-Learning, an individually-oriented organization of the educational process is no longer a utopia.

Its effectiveness directly depends on the motivation of students, their approach to learning, as well as on the ability to master the material on their own, and this primarily concerns learning in the e-Learning environment [8]. In theory, constructivism attracts many supporters, but in practice, regulations still dominate in our country, which is focused not on the student, but on the teacher as a communicator of knowledge.

Accordingly, the main attention is paid to his ability to qualitatively transfer knowledge, as well as educational and methodological material, its completeness and sufficiency for students to receive ready-made knowledge. At the same time, it turns out that an indicator of the quality of education is how accurately the student reproduces this ready-made knowledge. Hence the well-known difficulties with the (c) Kaschuck Kateryna 
implementation of the competence-based approach, since it concentrates precisely on the results of education, which are not understood as the sum of acquired knowledge, but the readiness to apply it to solve certain life situations.

The problem is that it is almost impossible to develop this ability without serious independent work of students. And it turns out a vicious circle: as a result of instructive learning, the student does not acquire the skill of active independent work, leading to the formation of new knowledge and personal experience, and without this skill, constructive learning, in particular, the implementation of an individual educational trajectory is problematic. As for e-Learning, the distance learning technology itself presupposes active independent work of students and, accordingly, motivation for it (Fig.1).

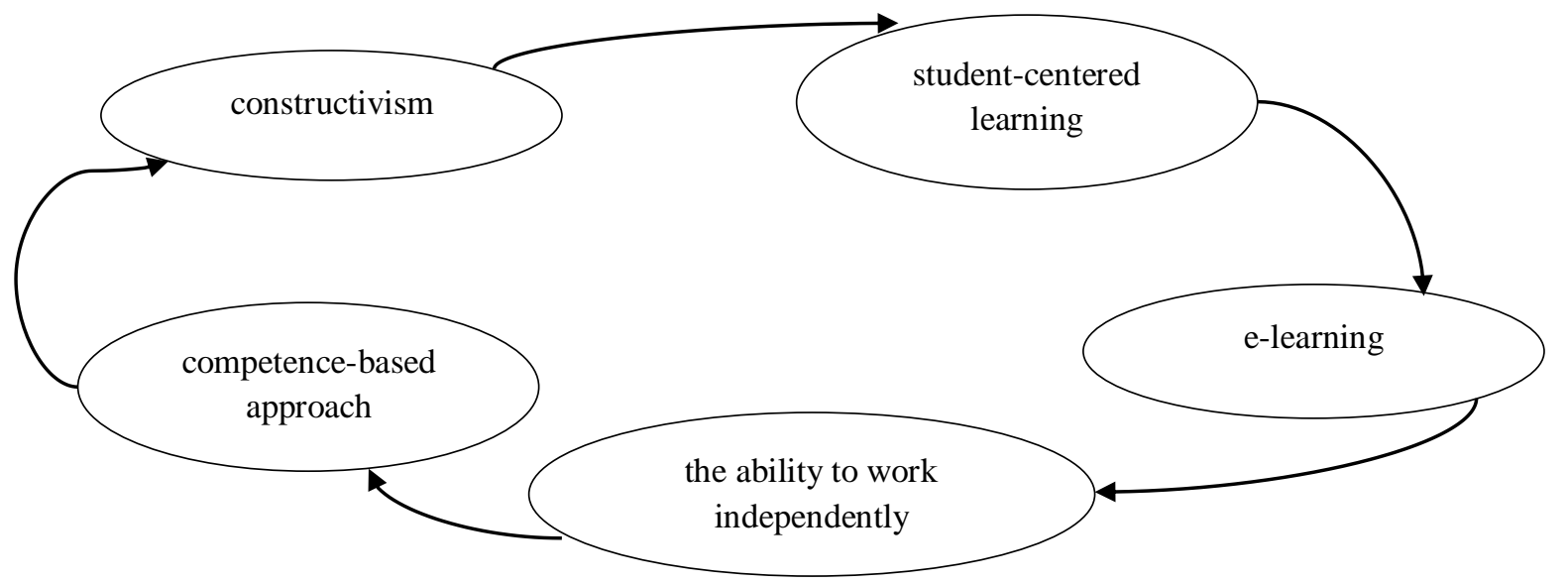

Figure 1. The chain of distant learning technology

According to a number of experts, it is with this ability to work independently that the situation is very unfavorable [5]. It remains only to agree with the opinion that the majority of students do not have a coherent life strategy, and therefore they are not able to take the maximum necessary knowledge out of the walls of universities. Having entered the university, the student, in theory, should begin to independently plan his studies, work (if any) and distribute the loads associated with them. However, not everyone is so perspicacious.

With a personalized, result-oriented organization of training, the student masters the educational program according to the individual curriculum. A 
systematic analysis of their goals, the fulfillment of their obligations, preparation and adjustment of their plans lead to the fact that the student becomes more organized, learns to manage his time. He consciously masters the ability to learn [14]. We believe that the student is able to systematically analyze his goals (and, first of all, set them), fulfill the obligations assumed (and be responsible for them), plan and adjust the program of action only if he already has the competence to selfmanagement and, in particular, time management.

These abilities can be learned by mastering the discipline "Selfmanagement". Training companies offer the implementation of programs for this course, since it is most in demand by entrepreneurs. In higher education programs, the elements of self-management are scattered, and if taught, then in a variety of disciplines - from general management to business image. True, in some universities the importance of this course is recognized. So, at the Zhytomyr State University named after I. Frank on specialty 073 "Management" is taught the course "Management and self-management" [6].

The essence of the course is very simple: in self-management, the main functions of management should be applied in relation to the person himself. The main functions of management are planning, organization, motivation and control. Therefore, he must possess the competencies of his own time effective planning, self-organization, self-control and self-motivation. Actually, these are the tasks that time management sets for itself, since the personal and team effectiveness of a person presupposes possession of the listed skills. Therefore, the lion's share of the didactics of the «Management and self-management» course is time management. The structure of the course includes consideration of such important issues as prioritization, self-motivation, goal setting, timing and time absorbers, planning, and review and control of tasks. In addition to competencies in the field of time management, self-management involves the development of soft skills such as energy management, creativity management and communication management.

We consider it necessary to consider the possibilities of time management in terms of the formation of competencies necessary for effective self-study in the e(c) Kaschuck Kateryna 
Learning environment. For the independent formation of an individual educational trajectory, the student must first of all have the skill of goal-setting. Often this does not happen, since not all students think proactively and build their lives on the basis of their goals [7]. Many, unfortunately, implement a reactive life strategy and live "as it develops", "as it turns out." That is why the topic of personal goal-setting in the time management course is at the forefront. Obviously, considering the topic of goal setting is not a prerogative time-management. So, in the course of general and strategic management, goal-setting is considered according to the Western SMART system, which designates the criteria for meeting the requirements for setting a goal. As for personal goal-setting, it is advisable to consider not only SMART criteria, but also a number of others, for example: how much the achievement of a goal depends on you personally, do you have the necessary resources, is your goal environmentally friendly?

In addition, it is necessary to consider also the so-called "non-projective approach" [12], implying work not with goals, but with meta-goals. It should be noted that the consideration of goal-setting technologies is preceded by work on the crystallization of personal values. It is important that the linking of "values" to "life goals" radically changes the students' understanding of this concept in principle. The fact is that in every self-respecting company, work has been carried out to determine corporate values designed to unite employees and promote their incorporation.

In practice, this work is carried out, as a rule, by invited PR specialists, and it ends with the posting of these values on the company's website. As a result, values remain a declaration and are perceived, in particular, by students as a Western delicacy, for some reason, desperately being implemented in Ukrainian companies. Working out the concept of "value" on personal examples radically changes the ideas of students, which subsequently apply to corporate values, be it the values of an educational organization or the company in which they work. And at the stage of training, this makes it significantly more meaningful and conducive 
to greater proactivity of students in building life plans in accordance with the set goals.

Logically, different planning technologies should be considered with students further, but not everything is so simple. The fact is that students tend to overestimate the available time resource [18], and therefore they use it very wastefully. Therefore, the topic of timekeeping and time absorbers is considered secondarily. Note that it is especially relevant in the conditions of remote learning, and even remote work, since a clear tracking of the time for certain types of activity disciplines both the student and the teacher. In addition, timing develops a sense of time and efficiency, which is invaluable in independent work.

Only after the student has learned to "feel the time", find its reserves and resist the time absorbers, do we move on to the study of planning technologies. Note that priority is given to tools for flexible, adaptive planning, which are especially relevant in the face of uncertainty and constant changes, for which today's life is so rich. As a result, students learn ways of planning their time, which will allow them to always be able to do the main thing, regardless of newly emerging circumstances and tasks. This is extremely important for individuals practicing on their own, as distractions unfortunately arise regularly.

Technologies for reviewing and controlling tasks is a particularly favorite topic at corporate trainings for managers, and this is no coincidence - review does not allow you to forget about tasks, control ensures tracking of their implementation. With regard to self-management, these functions are no less relevant, especially in the conditions of independent work. Simple and convenient tables and charts, which can be kept on paper and electronic media, allow you to keep your head busy with strategically important activities, and not with routine.

Considering the technologies of time management, one cannot but touch upon the topic of priorities, and we consider it from two angles - from the point of view of eliminating unnecessary things and concentrating on the main thing. Sifting out the excess allows you to "recover" from excessive reliability, and concentration on the main thing - to focus on vital issues, the solution of which @ Kaschuck Kateryna 
will bring the achievement of the goal closer. In the process of studying the course of time management, students master more than 30 practical methods of organizing time, which contribute to increasing its efficiency.

The task is to form a habit of using certain tools as needed. This habit is best developed in the game. To do this in time management there are techniques for working with tasks that you don't want to do at all. These can be huge and complex tasks, or small but unpleasant ones. The tools that allow you to painlessly cope with these kinds of tasks allow you to gradually form the habit of overcoming procrastination and consistently and continuously move towards your goal.

We believe that a time-management course, and ideally a self-management course, should serve as the basis for preparing for e-Learning and is ready to cope with the task of forming the competencies of goal-setting, planning, control and self-motivation - in short, everything that is necessary for effective independent work.

It is obvious that the result of a student's independent work is completed assignments that are sent to the teacher. It is equally obvious that the student carries out this independent work exclusively at a convenient time for himself. And, of course, he expects immediate feedback, resolutely not interested in how comfortable it is for the teacher to "drop everything" and start checking his work.

Since this time often approaches the deadline, the student is nervous about the lack of an immediate response, and the teacher, overwhelmed with work, physically does not have time to check everything in time. And that is not all. A fairly common situation in e-Learning is that a student simply misses the time for completing assignments and even the test time, possibly due to real workload. Of course, sooner or later, rather late, the student goes to connection and begins to take the teacher by starvation.

The militant student argument "I need a credit, otherwise I'll be expelled" completely interrupts the counter teaching arguments "very busy", "other things", "I have a day off". However, it also happens in another way, when students send 
their work on time, and the teacher, on the contrary, does not have time to look at these works and give feedback.

Therefore, a digital corporate culture should be formed in an educational organization. This is not only a digital educational environment, it is also the rules, regulations and standards of interaction in this environment of the administration, faculty and students. In particular, it is necessary to regulate the observance of the work schedule, the timing of the response to the letter, the provision of feedback. Then student-centered learning in the e-Learning environment will be comfortable and effective for both students and teachers.

Conclusion. It is obvious that e-Learning and blended-learning will remain in our lives forever. It is also very likely that student-centered learning with the development of e-Learning will spread, and over time will be introduced into traditional education programs. It is not yet clear how this will become real - it is extremely difficult, if not impossible, with the flow-group organization of training.

Productive learning is a daily reality. Therefore, children come to universities today, for whom productive learning is daily activities in schools that have introduced a developing educational system. That is, many children have already learned to think and discover new knowledge on their own. And the main task now is to accustom them to productive independent work aimed at the implementation of personal plans in accordance with the set life goals.

The Time Management course is quite capable of coping with this task as a basis for preparing for the transition to e-Learning. Topics of this course can be included as a key component in the course "Management" along with topics such as energy management, creativity, communication skills. The influence of these topics on the development of students' ability to work independently and, as a consequence, on the efficiency of their work, of course, also exists, and this topic is still waiting for its detailed consideration.

\section{References}


1. Webinar of UNESCO "Learning Cities respond to COVID-19". Retrieved from https://en.unesco.org/events/webinar-unesco-learning-cities-respond-covid-19 [in English].

2. Bakirov, V., \& Oharkov, M. (2021). Pandemiia mozhe nazavzhdy zminyty vyschu osvitu [A pandemic can change higher education forever]. Dzerkalo tyzhnia - Mirror of the week. Retrieved from https://zn.ua/ukr/EDUCATION/pandemijamozhenazavzhdi-zminiti-vishchu-osvitu.html [in Ukrainian].

3. Annual Report 2019 of UNESCO "UNESCO Institute for Lifelong Learning". Retrieved from https://uil.unesco.org/uils-annual-report-2019 [in English].

4. Site of UNESCO "Learning cities: Drivers of inclusion and sustainability". Retrieved from https://uil.unesco.org/lifelong-learning/learning-cities/learningcities-drivers-inclusion-and-sustainability [in English].

5. Bergmann, J., \& Sams, A. (2014). Flipped Learning: Gateway to Student Engagement. International Society for Technology in Education. Washington, DC: Eugene [in English].

6. Jensen, T. (2019). Higher Education in the Digital Era. The Current State of Transformation Around the World. International Association of Universities. P. $28-42$. Retrieved from https://www.iauaiu.net/IMG/pdf/technology_report_2019.pdf [in English].

7. Attard, A., Di Iorio, E., Geven, K., \& Santa, R. (2010). Student Centered Learning. An Insight into Theory and Practice. Bukarest: Education International, European Students Union, 82 p. Retrieved from http://www.ehea.info/Upload/document/consultive/esu/2010_T4SCL_An_Insight_ Into_Theory_And_Practice_565074.pdf [in English].

8. Wulf, C. (2019). «From Teaching to Learning»: Characteristics and Challenges of a Student-Centered Learning Culture. In: Mieg H.A. (Ed). InquiryBased Learning - Undergraduate Research. Springer, Cham, pp. 47-55 [in English]. 
9. Site of UNESCO "Supporting teachers and education personnel during times of crisis". Retrieved from https://unesdoc.unesco.org/ark:/48223/pf0000373338 [in English].

10. QS (2020). "How Covid-19 is Impacting Prospective International Students Across the Globe". Higher Education Policy for Minorities in the United States. Retrieved from http://hdl.handle.net/10919/98431 [in English].

11. Portal «Vyscha osvita» [Portal Higher Education]. "Dystantsijne navchannia" [Distant learning]. Retrieved from http://vnz.org.ua/dystantsijnaosvita/pro [in Ukrainian].

12. Oleshko A.A., \& Bondarenko S. M. (2020). Udoskonalennia systemy dystantsijnoho navchannia $\mathrm{u}$ vyschij shkoli $\mathrm{v}$ umovakh pandemii covid-19 [Improving the system of distance learning in higher education in the context of the COVID-19 pandemic]. Materialy mizhnarodnoi naukovo-praktychnoi konferentsii - International scientific-practical conference. (pp. 78-79). Kyiv: Kyiv National University of Technologies and Design [in Ukrainian].

13. Site of the State Service for the Quality of Education of Ukraine "Informatsijno-analitychna dovidka pro rezul'taty opytuvannia schodo stanu vykorystannia tekhnolohij dystantsijnoho navchannia u zakladakh vyschoi osvity Ukrainy" [Information and analytical report on the results of the survey on the state of use of distance learning technologies in higher education institutions of Ukraine]. Retrieved from www.sqe.gov.ua/index.php/uk-ua/vidkryti-dani [in Ukrainian].

14. Oleshko, A. \& Rovnyagin, A. (2020). Suchasni tendentsii mizhnarodnoi osvitnoi emihratsii $\mathrm{z}$ ukrainy [Modern tendencies in international educational emigration from Ukraine]. Investytsiyi: praktyka ta dosvid - Investments: practice and experience, vol. 3, 21-25 [in Ukrainian].

15. Brammer, S., \& Clark, T. (2020). COVID-19 and Management Education: Reflections on Challenges, Opportunities, and Potential Futures. British Journal of Management, vol. 31, 453-456 [in English]. 
16. Oleshko, A. \& Rovnyagin, A. (2020). Antykryzova polityka natsionalnykh derzhav u konteksti podolannia sotsialno-ekonomichnykh naslidkiv Covid-19 [Anti-crisis policy of national states in the context of overcoming the social and economic consequences of Covid-19]. Efektyvna ekonomika - Effective economy, vol. 4, 46-54 [in Ukrainian].

Стаття надійшла до редакиії 05.05.2021 